\title{
ELK RANCH ELK RANCH DETERMINATION OF ELIGIBILITY FOR THE NATIONAL REGISTER OF Historic Places
}

\begin{abstract}
$+2$
\section{$\uparrow$ Overview}

During summer 2010, the University of Wyoming American Studies Program offered "Field Studies in Historic Preservation: Elk Ranch Determination of Eligibility for the National Register of Historic Places." This 3-credit, upper-level undergraduate course introduced students to the process of documenting, evaluating and understanding historic buildings and cultural landscapes through field work. The course included readings, lectures, discussions, directed field work, archival research and writing. Students were given the opportunity to assist in fulfilling a contract with the National Park Service and to learn about how the park manages its historic and cultural resources. The course was taught by Research Scientist Mary Humstone, with assistance from University of Wyoming American Studies Folklife Specialist Andrea Graham and NPS Cultural Resource Specialist Katherine Longfield.
\end{abstract}

\section{MARY M. HUMSTONE $\uparrow$ AMERICAN STUDIES PROGRAM UNIVERSITY OF WYOMING $\uparrow$ LARAMIE}

\section{Course Background}

The eight students enrolled in the course conducted several days of research in Laramie before traveling to Grand Teton National Park. Students stayed at the UW-NPS Research Center for eight days, dividing their time between fieldwork, research in local archives and report writing. Fieldwork consisted of documenting the landscape and buildings of the Elk Ranch, a 2500-acre property near Moran, through photographs and narrative descriptions (Figure 1). Students also surveyed the property for archeological and other site features, which were mapped using a GIS system.

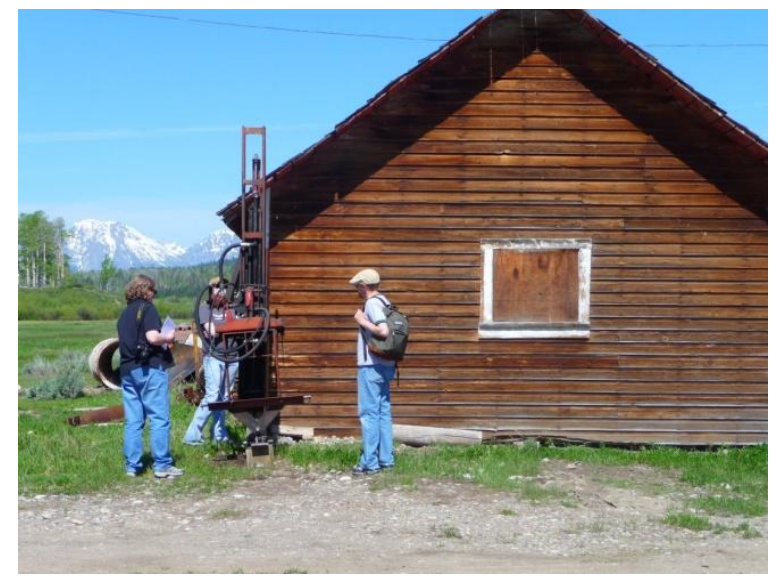

Figure 1. Students survey a historic barn at the Elk Ranch with the assistance of Andrea Graham (left). (Mary Humstone, 2010).

The fieldwork was supplemented by research in local archives, in particular Grand Teton National Park and the Jackson Hole Historical Society, to uncover the history of the ranch and determine its significance in the history of Jackson Hole and Grand Teton National Park. In addition, students conducted oral histories with several local ranchers with ties to the Elk Ranch, and participated in a demonstration of irrigating techniques on the ranch (Figure 2). The product of this field course was a determination of eligibility (DOE) for the National Register of Historic Places for the Elk Ranch.

In addition to the work directly related to the DOE, students had an opportunity to meet with cultural resources staff at the National Park Service to learn how the park evaluates, manages and interprets its cultural resources. In addition to staying at the historic AMK Ranch and exploring its historic and 
cultural resources, students visited several other historic properties in the park, including Mormon Row (Figure 3), the Hunter Hereford Ranch, the Luther Taylor Ranch and Colter Bay. They also spent an afternoon volunteering with the Western Center for Historic Preservation, applying roofing and chinking log walls at the White Grass Ranch (Figure 4).

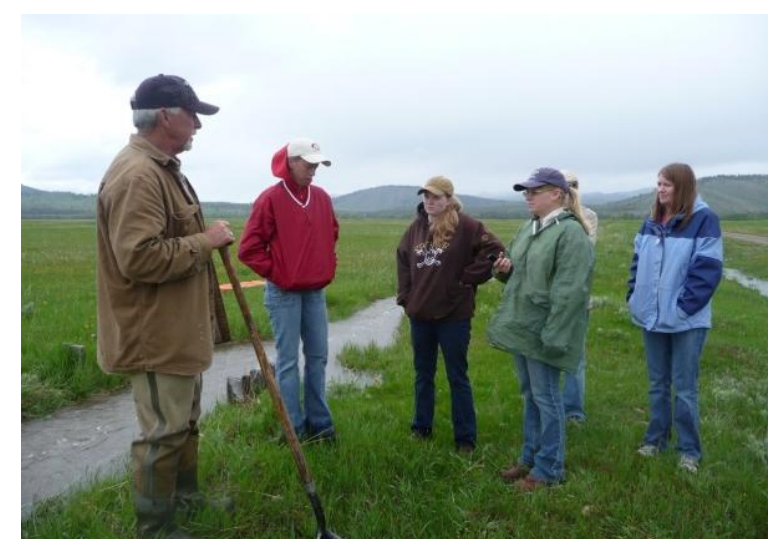

Figure 2. Students get a lesson in irrigation from Bill Lawrence of the National Park Service (Mary Humstone, 2010).

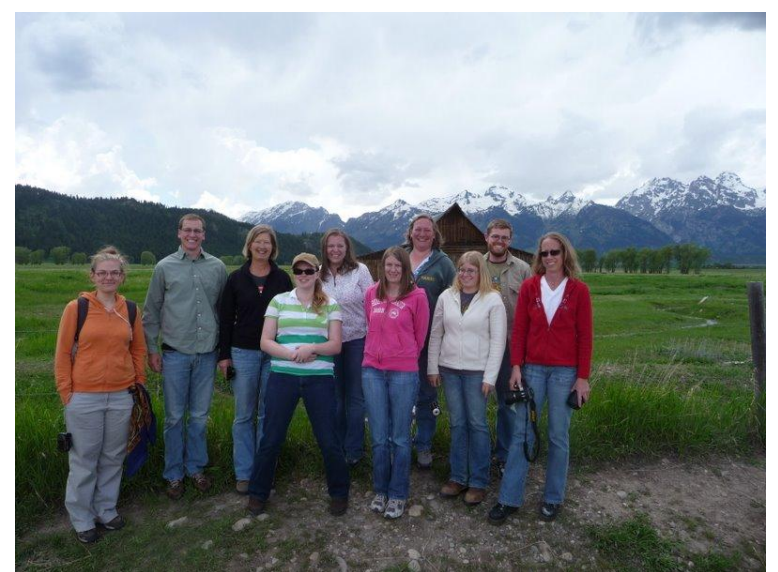

Figure 3. Students and faculty of "Field Studies in Historic Preservation" at Mormon Row (Katherine Longfield, 2010)

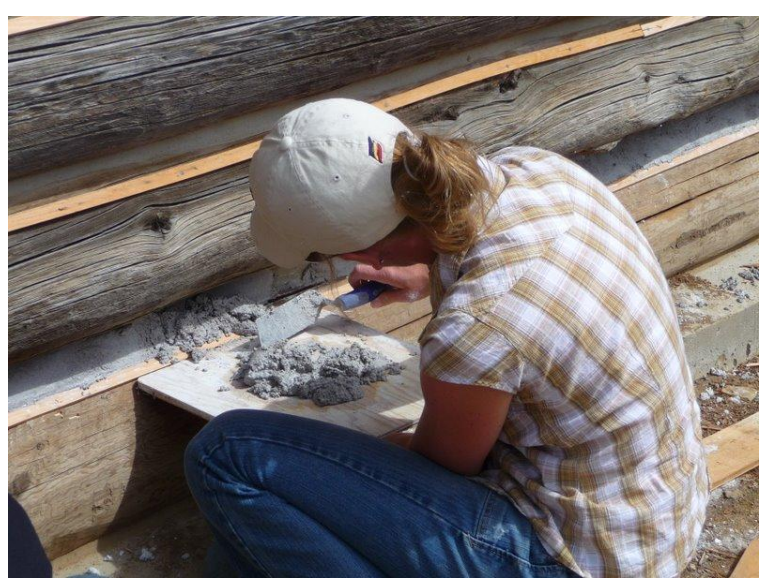

Figure 4. UW student applies daubing to log building at historic White Grass Ranch (Mary Humstone, 2010)

Through this field course students learned about park policies and procedures regarding historic preservation, and learned how to conduct historic preservation field work and prepare a professional report (Figure 5).

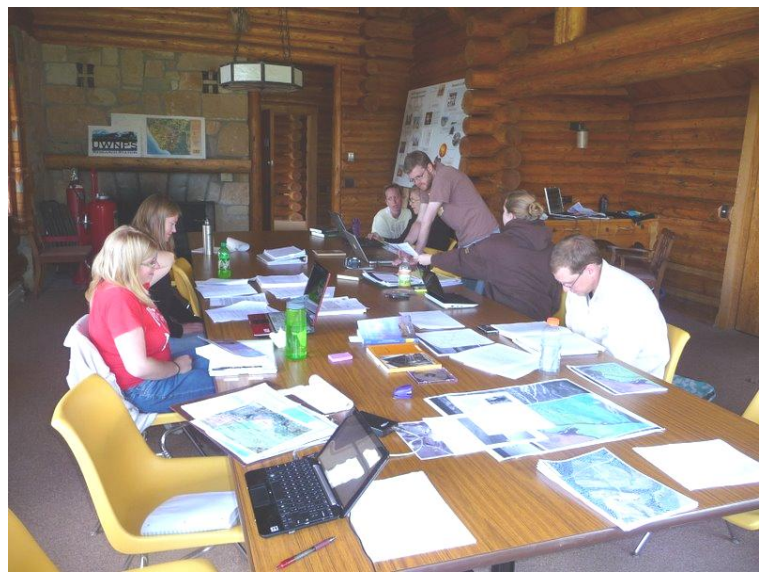

Figure 5. UW students work on the final report in the dining room of the Berol Lodge at the AMK Ranch (Mary Humstone, 2010) 